\title{
ПОДВИЖНАЯ ИГРА КАК СРЕДСТВО ВОСПИТАНИЯ ДРУЖЕСКИХ ВЗАИМООТНОШЕНИЙ У ДЕТЕЙ ДОШКОЛЬНОГО ВОЗРАСТА
}

\section{OUTDOOR PLAY AS A MEANS OF FOSTERING FRIENDLY RELATIONSHIPS IN PRESCHOOL CHILDREN}

\author{
E. Lebedeva \\ I. Koroleva \\ A. Mitrofanova \\ I. Sokolova
}

Summary: This article discusses the issue of the formation and education of friendly interpersonal relationships between preschool children. Fostering friendly relations among preschoolers is one of the most important goals set by teachers in their work. The relevance of this task in modern Russia is reflected in the Federal State Educational Standard for preschool education. In the description of the study, methods and techniques of specially organized work are revealed, including the selection and use of outdoor games, as well as methods for studying the level of formation of friendly relationships that correspond to the age and development of children.

Keywords: outdoor games, preschoolers, friendly relations, upbringing, development.
Лебедева Евгения Геннадьевна

Доцент, Вологодский государственный университет jenya1433@yandex.ru

Королева Ирина Валентиновна Старший преподаватель, Вологодский государственный университет

Митрофанова Анастасия Геннадьевна Старший преподаватель, Вологодский государственный университет

Соколова Ирина Юрьевна Старший преподаватель, Вологодский государственный университет

Аннотация: В данной статье рассматривается вопрос формирования и воспитания дружеских межличностных отношений между детьми дошкольного возраста. Воспитание дружеских отношений у дошкольников - это одна из важнейших целей, поставленных в своей работе педагогами. Актуальность данной задачи в современной России отражена и в Федеральном Государственном Образовательном Стандарте дошкольного образования. В описании проведенного исследования раскрываются методы и приемы специально организованной работы, включающую в себя подбор и использование подвижных игр, а также методики исследования уровня сформированности дружеских взаимоотношений, соответствующие возрасту и развитию детей.

Ключевые слова: подвижные игры, дошкольники, дружеские взаимоотношения, воспитание, развитие.

Для формирования адекватной самооценки ребенка, его уверенности в себе, очень важны дружеские взаимоотношения со сверстниками, которые создают чувство общности с группой других детей, что очень важно для общего эмоционального состояния. Если дружеские взаимоотношения по каким-либо причинам не складываются, ребенку очень неуютно в такой группе, он чувствует себя отверженным.

Не полностью сформированные отношения, или вовсе их отсутствие вызывают у ребенка состояние тревоги и стресса. Такое состояние требует выхода и, как правило, выливается в агрессию по отношению к сверстникам, либо в чувство собственной неполноценности и общее подавленное состояние. Впоследствии у ребенка формируются отрицательные черты личности, неприязнь, агрессивность, враждебность, отрицательное отношение к другим людям. В последнее время многие педагоги стали отмечать, что детей с подобным агрессивным поведением становится все больше, и работать с такими детьми все сложнее. Усугубляется такое положение тем, что ни педагоги, ни психологи, ни родители не знают, как справляться с таким поведением детей, так 
как традиционные методы воспитания не приносят желаемого результата [2].

Я.Л. Коломинский утверждает, в старшем и подготовительном дошкольном возрасте взаимоотношения между сверстниками становятся более стабильными, не зависящими от внешних обстоятельств, чего нельзя сказать о более раннем возрасте. Для возникновения между детьми дружеских взаимоотношений необходимым условием являются такие качества ребенка, как: умение договариваться, учитывать интересы других детей, сопереживать сверстникам и способность разрешать конфликты. Именно формирование дружеских взаимоотношений в дошкольном возрасте является условием для проявления и развития начал коллективных взаимоотношений [3].

Каким образом можно способствовать развитию дружеских взаимоотношений у дошкольников? Как педагог может поддерживать и закреплять такие взаимоотношения? Через ведущую деятельность детей дошкольного возраста - игру, которой принадлежит ключевая роль в развитии и воспитании ребенка. Но игра также является и эффективным средством формирования моральных и волевых качеств личности дошкольника. Именно в игре ребенок реализует свою потребность воздействовать на окружающий его мир. Таким образом, игра оказывает существенное влияние на психику дошкольника, формирует все стороны личности ребенка в единстве и взаимодействии. Наблюдая за играющим ребенком, можно узнать об его интересах, представлениях об окружающей жизни, выявить особенности характера и темперамента, отношение к товарищам, взрослым и самому себе.

В разных видах игр единство и взаимодействие проявляются по-разному. В творческой игре, в замысле, в содержании игры, в связанных с игрой переживаниях отражаются все стороны личности ребенка. От широты замысла, от степени увлеченности им зависят и сила эмоций, и способность к волевому и умственному усилиям.

Значительное место среди разнообразных видов игровой деятельности, используемых в практике дошкольного образования, занимают подвижные игры. Такие игры особенно любят дети, так как они позволяют удовлетворить двигательную потребность и вызывают положительные эмоции. Подвижные игры с правилами помогают педагогу воспитывать в детях самостоятельность, инициативу, активность, справедливость, умение помочь и поддержать сверстников, умение действовать сообща, четко выполнять правила [4].

Целью нашего исследования является изучение влияния подвижных игр на формирование дружеских взаимоотношений у детей дошкольного возраста.

Исследование проводилось на базе МДОУ №3 «Воро- бушек» г. Вологды. В исследовании принимали участие 40 детей шестого года жизни, которые были поделены нами на две группы - контрольную, в которую входило 20 детей и экспериментальную, где участвовало также 20 детей. На констатирующем этапе исследования нами был выявлен актуальный уровень сформированности дружеских взаимоотношений у детей старшего дошкольного возраста, проанализирована степень эмоционального комфорта во время пребывания в детском саду и особенности взаимодействия детей в группе. Для решения данных задач нами использовались следующие методы: наблюдение и беседа с детьми, анкетирование родителей воспитанников, методика Т.А. Репиной «Секрет», методика «Моя любимая группа».

Методика «Секрет» применялась индивидуально. Ребенку предлагалось, в тайне от других детей, подарить 3 картинки трем детям. Сначала самую красивую на его взгляд, затем менее красивую и т.д. После обработки результатов была получена информация о том, какой статус имеет ребенок среди сверстников. В экспериментальной группе детей с высоким статусом оказалось 10\%, со средним - 55\% детей и с низким - 35\%. В контрольной группе ситуация оказалась примерно такой же: $15 \%$ детей с высоким статусом, 47\% - со средним и $38 \%$ детей с низким социальным статусом.

В индивидуальной беседе выявлялось общее оценочное отношение к другим детям, а также представления детей о состоянии сверстника, его переживаниях и своих собственных. Результаты беседы в обеих группах оказались также примерно одинаковыми: почти в половине случаев дети давали сверстникам отрицательную или неоднозначную оценку, около $30 \%$ не хотели помочь сверстникам в случае затруднений и примерно $20 \%$ детей не могли описать собственные эмоции и чувства.

В целях получения дополнительной информации о сформированности дружеских взаимоотношений у дошкольников в обеих группах было проведено анкетирование родителей воспитанников. Полученные данные показали, что, по мнению родителей, большинство детей помогают друг другу только по просьбе сверстника или взрослого, в группе преобладают избирательные отношения между детьми и почти половина дошкольников довольно часто вступают в конфликты.

Рисуночная методика «Моя любимая группа» была использована для выявления степени эмоционального комфорта во время пребывания в детском саду, а также для оценивания отношения детей к воспитателям и к сверстникам в группе. Каждому ребенку было предложено нарисовать рисунок на предложенную тему, затем проводилась беседа о том, что изображено на рисунке. Эмоционально благополучных рисунков оказалось немного: в экспериментальной группе - 25\%, в контрольной - 32\%. Условно благополучных рисунков, соответственно 48\% и 40\%. Неблагополучных рисунков, 
свидетельствующих о трудностях, которые дети испытывают в общении со сверстниками, оказалось $27 \%$ и $28 \%$ соответственно.

На основании сводных результатов проведенных диагностик был выявлен уровень сформированности дружеских взаимоотношений у детей старшего дошкольного возраста в экспериментальной и контрольной группах. В обеих группах он оказался примерно одинаковый, преимущественно средний. Уровень эмоционального комфорта каждого ребенка оказался невысоким. Также нами выявлена недостаточная сформированность умения находить решение в спорной и конфликтной ситуации, неумение обговаривать и согласовывать свои действия в игровой деятельности, недостаточный уровень развития сочувствия и сопереживания к участникам совместной игровой деятельности. На основе проанализированных данных констатирующего эксперимента нами была разработана методика опытноэкспериментальной работы.

На этапе формирующего эксперимента нами были определены подвижные игры как средство формирования дружеских взаимоотношений у детей дошкольного возраста. Все подвижные игры в соответствии с целью исследования были нами объединены в четыре группы: игры, развивающие умение согласовывать свои действия со сверстниками; игры, направленные на умение договариваться друг с другом; игры, приучающие детей свободно взаимодействовать друг с другом; игры, формирующие коллективные взаимоотношения.

Среди подвижных игр, направленных на развитие умения согласовывать свои действия со сверстниками нами использовались такие игры, как: «Ниточка и иголочка», эстафеты, «Поводырь», «Звери в болоте», «Тень» и др. Большое удовольствие от игр «Тень» и «Звери в болоте» получали дети с низким уровнем самооценки, чувствуя себя более уверенно в коллективе товарищей. А у детей, имеющих высокую популярность в группе, появилась хорошая возможность проявить внимание и заботу о других сверстниках. Всем детям понравилось оказывать помощь слабым в играх «Гуси-лебеди» и «Два мороза» [5].

Ко второй группе игр, способствующих формированию умения договариваться друг с другом, относилась игра «Где мы были, мы не скажем, а что делали - покажем», которая была проведена на начальном этапе эксперимента, где детям было необходимо советоваться друг с другом и прислушиваться к мнению сверстников. Лидерам группы не удавалось следовать правилам, и они пытались показать свои сюжеты. В итоге педагогу удалось отрегулировать отношения между детьми и научить их договариваться друг с другом. Также в играх «Поймай хвост дракона» и «Сороконожка», относящихся к этой же категории игр, уже была видна динамика развития отношений между детьми - они с удовольствием договаривались и следовали правилам игры.

К играм, приучающим детей к свободному взаимодействию друг с другом, были отнесены такие игры, как «Кто позвал?», «Эхо», «Волны» и др. Так, в игре «Кто позвал?» поначалу проявляли инициативу только популярные дети, но впоследствии в игру влились все остальные. В игре «Волны» непопулярным детям в начале экспериментальной работы было тяжело проявлять себя, и педагогу приходилось напоминать, что в море все дети одинаковы, и волны ласкают всех детей без исключения.

В последнюю группу игр, направленных на формирование коллективных взаимоотношений вошли такие игры, как «Обнимашки», «Паровоз и вагоны», «Кто дальше укатит обруч», «Передай движение», «Игра в тарелочку» и др. Всем детям нравились игры с закрытыми глазами, в них проявляли инициативу абсолютно все. В игре «Гномики» дети учились радоваться за товарищей и проявлять сострадание, а преодолевать стеснение - в игре «Волшебный бубен». В играх «Из семечка в цветок» и «Передай движение» изначально непопулярные дети чувствовали себя нужными и необходимыми. На данном этапе нашей работы уже были видны изменения во взаимоотношениях дошкольников по сравнению с началом исследования: дети советовались, прислушивались друг к другу, договаривались о том, как лучше выполнить то или иное задание, поддерживали слабых, совместно обсуждали результаты по окончании игры.

На контрольном этапе изучалась эффективность проделанной нами работы. Повторная диагностика по тем же методикам, которые применялись на констатирующем этапе, показала, что в экспериментальной группе детей ситуация изменилась. Количество дошкольников с высоким социальным статусом повысилось на 27\% (на констатирующем этапе их было 10\%, на контрольном $37 \%)$, со средним уровнем уменьшилось на 7\% (55\% и 48\%), низкий уровень также уменьшился на 18\% (35\% и 17\%). Дети стали больше сопереживать друг другу, появилось желание помочь не по просьбе, а по собственному желанию. При проведении индивидуальной беседы было установлено, что детей, положительно оценивающих сверстников, стало на 32\% больше, чем на констатирующем этапе эксперимента. Большинство детей хотели бы оказать свою помощь сверстнику, сопереживали их состоянию в трудных ситуациях.

Анализ анкетирования родителей детей из экспериментальной группы выявил общее повышение дружелюбности дошкольников. При этом родителями было отмечено, что дети с большим желанием стали посещать детский сад, меньше вступают в конфликтные ситуации, больше сопереживают и сочувствуют окружающим, проявляют инициативу в оказании помощи родителям и сверстникам. 
Результаты, полученные при проведении рисуночной методики «Моя любимая группа», также показали улучшение качества взаимоотношений дошкольников в группе. Количество эмоционально благополучных и условно благополучных рисунков в экспериментальной группе детей увеличилось по сравнению с констатирующим этапом (36\% и 53\%). Анализ рисунков говорит о том, что дети стали больше общаться со сверстниками, более доверительные отношения установились и с воспитателем. Количество неблагополучных рисунков сократилось до $5 \%$.

Обобщенный уровень сформированности дружеских взаимоотношений у детей экспериментальной группы в целом повысился: количество детей с высоким уровнем повысилось на 16\%, со средним - на 7\%, с низким уровнем уменьшилось на 19\%. В контрольной группе показатели остались на прежнем уровне.
Качественный анализ результатов проведенного исследования показал, что у детей из экспериментальной группы стало более выражено умение согласовывать свои действия со сверстниками, повысилась самооценка, они легче устанавливают контакт с собеседником, более четко и ясно выражают свои мысли и желания, всегда готовы прийти на помощь товарищу и поддержать слабого.

Таким образом, нами была разработана и экспериментально апробирована методика организации физкультурно-оздоровительной работы, включающая в себя систему подвижных игр, направленных на формирование дружеских взаимоотношений у дошкольников. В ходе проведенного исследования было доказано, что подвижные игры имеют большой педагогический потенциал, который необходимо использовать для формирования дружеских взаимоотношений у детей дошкольного возраста.

\section{ЛИТЕРАТУРА}

1. Федеральный государственный образовательный стандарт дошкольного образования: Приказы и письма Минобрнауки РФ. / Москва: ТЦ Сфера, 2017. - 96 с.

2. Коган 0.Н. Эффективность физических занятий игровой направленности в специализированном дошкольном учреждении: автореф. дис. канд. пед. наук. / Коган Олег Николаевич; - Челябинск, 2000. - 22 с.

3. Коломинский Я.Л. Психология взаимоотношений в малых группах / Я.Л. Коломинский. - Минск, 1976. - 237 с.

4. Степаненкова Э.Я. Методика проведения подвижных игр / Э.Я. Степаненкова. - Москва: МОЗАИКАСИНТЕЗ, 2009. - 60 с.

5. Шмонина В.А. Творческие подвижные игры / В.А. Шмонина. - Москва: Дошкольное воспитание, 2011. № 8. - $40-44$ с.

( Л Лебедева Евгения Геннадьевна (jenya1433@yandex.ru), Королева Ирина Валентиновна, Митрофанова Анастасия Геннадьевна, Соколова Ирина Юрьевна

Журнал «Современная наука: актуальные проблемы теории и практики» 